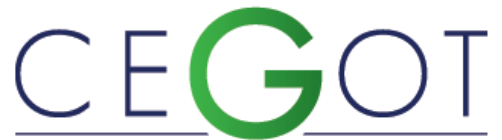

Centro de Estudos de Geografia e Ordenamento do Território
Geografia e Ordenamento do Território, Revista Eletrónica Centro de Estudos de Geografia e Ordenamento do Território http://cegot.org

COSTA, SANDRA

Universidade do Vale do Paraíba, Departamento de

Planejamento Urbano e Regional

Av. Shishima Hifumi, 2911 - Urbanova, CEP 12244-000, São José dos Campos,

São Paulo, Brasil

sandra@univap.br

MARINeLo, SAMUEL

Universidade do Vale do Paraíba, Departamento de

Planejamento Urbano e Regional

CEP 12244-000, São José dos Campos, São Paulo, Brasil

samuelmarinelo@gmail.com

\title{
O visível e o invisível da agricultura urbana em São José dos Campos, SP
}

The visible and invisible of the urban agriculture of São José dos Campos, SP

Referência: Costa, Sandra; Marinelo, Samuel (2019). O visível e o invisível da agricultura urbana em São José dos Campos, SP. Revista de Geografia e Ordenamento do Território (GOT), n. ${ }^{\circ} 16$ (março). Centro de Estudos de Geografia e Ordenamento do Território, p. 99-123, dx.doi.org/10.17127/got/2019.16.005

\section{RESUMO}

A agricultura urbana, estabelecida na cidade de São José dos Campos, São Paulo, revela situações muito particulares: agricultores que conservam características tradicionais do campesinato e desenvolvem hortas urbanas para fornecer alimentos aos moradores do entorno. Esses lugares, muitas vezes, não são "visíveis" ao poder público local, que estabelece políticas sem considera-los, ou mesmo considerando-os marginais ao processo decisório. Considerando esses aspectos, esse artigo apresenta uma discussão sobre a agricultura visível e invisível na cidade de São José dos Campos, SP, quem são seus condutores, suas visões de mundo e como o Poder Público os considera. Foram realizadas entrevistas com os agricultores e representantes do poder público local. Vários recortes territoriais são preenchidos por essas atividades, que mantém vivo as memórias afetivas da população.

Palavras-chave: Agricultura Urbana, Modos de Vida, Planejamento Urbano.

\section{ABSTRACT}

Urban agriculture, established in the city of São José dos Campos, São Paulo, reveals particular situations. One of them is the small producers that preserve traditional characteristics of the peasantry, and develops the planting of urban gardens to provide food to the residents of the surrounding area. These places are often not "visible" to local public power, which establishes policies without considering them, or even considering as peripheral to the decision-making process. Considering these aspects, this article presents a discussion about visible and invisible agriculture in the city of São José dos Campos, SP, who are its drivers, their visions of the process and how the Public Power considers them. This research carried out interviews with the farmers and representatives of the local public power. Several territories have these activities, which keeps alive the affective memories of the population. 
Keywords: Urban Agriculture, Ways of Life, Urban Planning.

\section{Introdução}

As políticas públicas urbanas foram desenvolvidas com vias à criação de legislações e desenvolvimento de mentalidades a respeito da formação das cidades. Segundo Vainer, essas políticas forçaram a escolha, de forma explícita ou implícita, de um modelo ideal de cidade fundeado em modelos de planos urbanos que podem ser representados, segundo o autor, por "um embate entre duas utopias urbanas: de um lado tem-se a utopia da cidadeempresa, da cidade mercadoria, da cidade negócio e de outro lado tem-se a utopia da cidade democrática" (VAINER, 2003, p.27).

Para Vainer (2003), o primeiro modelo está pautado na promoção de cidades globais, segundo o qual, via de regra, o fomento e crescimento urbano são regulados por representantes particulares e individuais (firmas) que direcionam o modelo de cidade para se adequar ao mercado de capitais mundial, produzindo equipamentos urbanos ligados às demandas da economia global, da competitividade internacional, muitas vezes ligados a um marketing urbano. No segundo modelo, dirigido pela política, preconiza-se a "construção" de cidadãos que, ao se formarem como tal, constroem também a cidade, que por sua vez não defende uma adequação aos modelos ligados ao desenvolvimento do capital (VAINER, 2003).

Ressalta-se que nesses planos de urbanização de cidades, ligados a qualquer uma das utopias urbanas, nem sempre as especificidades dos moradores urbanos são consideradas. Ao mesmo tempo, não é usual desenvolver estudos que tenham por objetivo, mínimo, detectar áreas que supostamente não estejam ligadas ao processo modernizador das cidades.

Santos, quando comenta sobre a mudança de conteúdo das regiões urbanas e agrícolas, alerta que "essa nova região urbana compreende, também, por contiguidade, as áreas que não são diretamente tocadas pelo processo modernizador e podem, desse modo, manter aspectos tradicionais ou arcaicos no interior de uma zona motora" (SANTOS, 1997, p. 69). Nesse aspecto, as áreas urbanas não podem ser tratadas como áreas homogêneas, em que 
a população residente deva ser moldada em um só tipo de plano urbano, esteja ele ligado a qualquer natureza utópica.

É nesse sentido que esse artigo se estruturou. Na cidade de São José dos Campos, São Paulo, há moradores que conservam características tradicionais do campesinato, desenvolvem o plantio de hortas e pomares urbanos em uma APP (Área de Proteção Permanente), que margeia o rio Paraíba do Sul, invisível ao Poder Público local, assim como há áreas de plantio, na área urbana, que apesar de explicitamente visíveis, nem sempre esses agricultores se inserem na cidade real.

Nesse sentido, esse artigo pretende apresentar a situação das áreas urbanas agricultadas na cidade de São José dos Campos, o invisível e o visível da agricultura urbana, quem são esses "agricultores" e investigar como o Poder Público Municipal percebe essas atividades e os seus envolvidos.

Para a elaboração da presente pesquisa foi necessário delimitar um objeto de estudo, fundeado naquilo que se convencionou chamar mundialmente de agricultura urbana e/ou periurbana. Ocorrente em pelo menos dois modais, a agricultura urbana estende-se tanto pelas atividades desenvolvidas em áreas particulares, como em terrenos vazios, quintais e áreas de concessão, como em áreas públicas, praças, fundos de vale, várzeas de cursos d'água e áreas de proteção ambiental. Atualmente, essa agricultura urbana é desenvolvida em inúmeras cidades do país (Almeida, 2011, Madaleno, 2002, Coutinho, 2007) e do mundo (Smit, J.; Ratta, A.; Nars, J, 1996, Donadieu, 2006, Ingersoll, R.; Fucci, B.; Sassatelli, M, 2007).

Para o desenvolvimento dessa pesquisa, tornou-se necessária uma análise de legislações, normatizações, diretrizes e parâmetros relacionados ao uso e ocupação do solo, ao planejamento e planos urbanos, além da agricultura urbana e suas práticas (Lei Complementar 306/06 - Plano Diretor de Desenvolvimento Integrado; Lei Complementar 428/10 - Lei de Zoneamento, uso e ocupação do solo do município de São José dos Campos; Novo Código Florestal Brasileiro (BRASIL, 2012). Houve levantamento de dados por meio de pesquisa de campo e realização de entrevistas com moradores e moradores/agricultores do bairro Jardim Altos de Santana, na zona norte do município de São José dos Campos, por estarem localizados em área de preservação permanente, além de se realizar algumas entrevistas com representantes do Poder Público Municipal. A aplicação das entrevistas aos 
moradores agricultores e aos representantes do poder público foram aprovadas pelo Comitê de Ética em Pesquisa da UNIVAP (no 14648813.4.0000.5503). O procedimento inicial foi o de levantamento do número de envolvidos na atividade para escolha e aplicação dos formulários pelo sistema de amostragem, respeitando a margem de $40 \%$ de indivíduos envolvidos com essa prática, ou seja, dezesseis pesquisados. Com os dados obtidos, foi possível compreender o perfil socioeconômicos das pessoas envolvidas direta e indiretamente com as práticas da agricultura urbana, levantamento da evolução histórica da prática da agricultura urbana na área, bem como os procedimentos, a administração e utilização do espaço agricultado. Alguns representantes do poder Público Municipal foram entrevistados, para permitir a compreensão da forma como o governo enxerga essa prática. Dados dos Censos Demográficos de 1960 a 2010, disponíveis para a cidade de São José dos Campos foram utilizados para compor a compreensão das relações existentes entre a prática da agricultura urbana e o uso e ocupação do solo (área em questão). Foram gerados dois croquis sobre a agricultura urbana na cidade de São José dos Campos, os quais foram elaborados utilizando imagens de satélite disponíveis no Google Earth, imagens obtidas em campo de vários trabalhos de campo, realizados entre março de 2012 e janeiro de 2014.

\section{O urbano, a cidade e o rural}

Por vezes, os termos urbano/urbanização são utilizados para dar sentido às noções de cidade, contudo é necessário esclarecer que cidade e urbano são conceitos distintos. Não raro se observa literaturas em que ocorre constantemente uma confusão desses termos, assim fica o questionamento: o que é o espaço urbano? O Professor Milton Santos explica que cidade e urbano são complementares, porém conceitualmente distintos quando afirma que "o urbano é frequentemente o abstrato, o geral o externo. A cidade é o particular, o concreto, o interno" (SANTOS, 1994, p. 15), ou seja, o conceito de cidade está ligado às visões particulares de um espaço construído. É como se, ao analisar um espaço urbano, dele fosse emancipada toda noção generalizada e abstrata do termo em questão e se passasse a visualizar apenas as noções do que é concreto e particular, das relações internas, características particulares da noção de cidade. 
A cidade, que representa o espaço concreto, compreende toda a materialidade que comporta um modo de vida coletivo, incluindo as infraestruturas, os equipamentos e os fluxos que se desenvolvem nesse espaço, contudo representa também o cidadão e toda a sua ação ou inação nesse espaço. "A cidade nasce como um local inerente ao cidadão" (ABIKO, 1995, p. 9).

Evidencia-se, assim, a relação existente entre a produção do espaço e o espaço urbano. Gottdiener explicita que, nos dias atuais, "a forma que o espaço urbano adquire é a materialização do desenvolvimento contínuo do capitalismo" (GOTTDIENER, 1993, p. 54). Nesse aspecto, a morfologia espacial urbana está intrínseca e dialeticamente relacionada às mudanças das estruturas da organização social, ou seja, conforme mudam as formas de produção econômico sociais, muda também a configuração do espaço, principalmente o urbano, tão espacialmente ligado aos modos de produção.

Dessa maneira a cidade passa a ser considerada o espaço de maior raio de ação da sociedade dita desenvolvida, ao passo que, se o conceito de espaço está ligado à interrelação entre os diferentes modais de uso e ocupação do solo, automaticamente, há uma superposição de importância das áreas urbanas por sobre as áreas ainda majoritariamente rurais.

Apesar da emancipação natural do meio rural, as mudanças que ocorreram na cidade relacionam-se ao campo, uma vez que foi a partir dos avanços das técnicas agrícolas e da consequente produção de excedentes de alimentos que as populações criaram as primeiras aldeias, que se configurariam como os primórdios das cidades.

Santos (2008) afirma que

\footnotetext{
as cidades puderam formar-se graças a um determinado avanço das técnicas de produção agrícola, que proporcionou a formação de um excedente de produtos alimentares. Com a existência desse excedente, algumas pessoas puderam dedicar-se a outras atividades, sendo a cidade, predominantemente, lugar de atividades não agrícolas (SANTOS, 2008, p. 59).
}

Verifica-se, assim, que nesse período histórico, o desenvolvimento das cidades está associado ao desenvolvimento da agricultura, como se o surgimento da primeira dependesse, majoritariamente, do sucesso da segunda. No período Clássico, essas relações irão diminuir, mas a ligação existente entre o desenvolvimento das cidades e o 
desenvolvimento da agricultura irá se fortalecer ao longo do tempo, dando à agricultura um papel decisivo no desenvolvimento do mundo urbano (ABIKO, 1995, p. 9). Durante o período do Feudalismo, o campo voltou a ter importância, como no início do mundo urbano, e as cidades perderam o status de centros comerciais e administrativos, uma vez que a economia da sociedade desse período era baseada na produção agrícola dos feudos (ARRUDA, 1993 p. 48).

Ocorre uma articulação entre os espaços, a superposição se torna visível quando se é possível identificar o espaço urbano se apropriando do espaço rural, este segundo entendido, classicamente, a partir da definição de Marques, como sendo

[...] um meio específico de características mais naturais, do que o urbano, que é produzido a partir de uma multiplicidade de usos, nos quais, a terra ou o "espaço natural", aparece como um fator primordial, o que tem resultados muitas vezes na criação e recriação de formas sociais de forte inscrição local (MARQUES, 2002, p. 109).

Atualmente, esse espaço apresenta novas características, uma vez que o processo de globalização atingiu o campo implicando em mudanças conceituais, com o rural sendo entendido como área sujeita a apropriação do capital e seu desenvolvimento (CARLOS, 2004, p. 9).

Nesse artigo adotamos a definição de rural mais ligada à ideia de espaço de criação e recriação de formas sociais, a fim de abordar as relações sociais estabelecidas no meio rural, mesmo que estas ocorram em áreas urbanas ou periurbanas. De acordo com essa direção, fica evidenciada que a corrente de pensamento aqui tratada tange no sentido de entender que os meios rural e urbano sejam complementares, uma vez que se articulam, como salienta Manfio, ao afirmar que "o meio urbano e rural estão sempre se articulando, pois existem cada vez mais espaços rurais dentro das cidades, principalmente das de maior dimensão e população. Além, de o rural influenciar o dinamismo das pequenas cidades ou das chamadas rurais" (MANFIO, 2011, p. 79). Assim, pode-se deduzir que, guardadas as devidas proporções de caso a caso, determinações existentes sobre o espaço rural possam também ser aplicadas ao meio urbano e vice-versa, uma vez que essas determinações se aplicam muito mais ao ser social do que ao espaço habitado. 


\title{
2.1. A cidade, a agricultura urbana e sua percepção pela população
}

Agricultura urbana é um conjunto interdisciplinar de atividades que inclui, por exemplo, a produção agrícola, o extrativismo e a pecuária, desenvolvidas nas áreas internas das cidades, ou mesmo nas zonas periurbanas, ou seja, no entorno das áreas estritamente urbanas. Essas atividades balizam-se pela participação da população urbana e periurbana nas áreas de cultivo, sempre agregadas as práticas de conhecimento local. Por definição, Santandreu e Lovo afirmam que

\begin{abstract}
a agricultura urbana é um conceito multidimensional que inclui a produção, a transformação e a prestação de serviços, de forma segura, para gerar produtos agrícolas (hortaliças, frutas, plantas medicinais, ornamentais, cultivados ou advindos do agroextrativismo, etc.) e pecuários (animais de pequeno, médio e grande porte) voltados para o autoconsumo, trocas e doações ou comercialização, (re) aproveitando-se, de forma eficiente e sustentável, os recursos e insumos locais (solo, água, resíduos, mão de obra, saberes, etc.). Essas atividades podem ser praticadas nos espaços intraurbanos ou periurbanos, estando vinculadas às dinâmicas urbanas ou das regiões metropolitanas e articuladas com a gestão territorial e ambiental das cidades (SANTANDREU \& LOVO, 2007, p. 11).
\end{abstract}

Desta forma a agricultura urbana apresenta uma nova ideia de paisagem verde urbana, uma vez que é produtiva, recreativa, e esteticamente diferente das noções de áreas verdes urbanas presentes no senso comum das sociedades urbanas. Além dessa diferenciação, a agricultura urbana promove a conservação e o desenvolvimento dos saberes locais. Sendo assim, essa atividade está ligada de forma direta e intrínseca com os níveis de percepção ambiental e topofilia dos que se apropriam dela. Surge aqui um novo campo a ser explorado, a agricultura urbana atrelada a percepção ambiental, assunto tratado adiante.

Para Mougeot (2000), a agricultura urbana ocorre no interior da cidade, ou ao seu redor. Segundo o autor, as características intra-urbanas interferem na sua localização, em todos os possíveis espaços da cidade. Pode ser executada de forma individual, em canteiros entre vias de circulação, ou deforma coletiva, em locais privados ou públicos. O autor ainda menciona que a implantação da atividade agrícola nesses espaços urbanos transforma essas áreas em ambientes produtivos e pode oferecer melhor qualidade de vida a comunidades locais (MOUGEOT, 2000).

Essa nova paisagem verde urbana que trata dos espaços produtivos do ponto de vista agrícola, normalmente está ligado a produtores - agentes do espaço - que tem algum sentimento simbólico com a prática do cultivo. Tuan afirma que "quando é irresistível, podemos estar certos de que o lugar ou meio ambiente é o veículo de acontecimentos 
emocionalmente fortes ou é percebido como um símbolo" (TUAN, 1980, p.107), assim devese incluir, em qualquer análise da percepção ambiental, os laços afetivos dos indivíduos, não só com o espaço físico do lugar, mas com seus sentimentos e leituras simbólicas do espaço e das atividades nele desenvolvidas.

Segundo Tuan, "o apego à terra do pequeno agricultor ou camponês é profundo. Conhecem a natureza porque ganham a vida com ela" (TUAN, 1980, p.111). Assim, essa relação pode ser de amor ou de ódio, afinal é a partir da produção que essa terra desenvolver que nascerá também a natureza do sentimento topofílico do lugar em questão.

Dessa forma, deve-se entender também que a posição social 'exercida' pelo agricultor sirva também como determinante de sua relação topofílica ou topofóbica com o lugar. $\mathrm{Na}$ maioria dos casos, agricultores que ocupam lugar mais privilegiado de status social, garantem construções de laços afetivos com o lugar num viés muito mais positivo do que negativo, afinal, conforme Tuan "o sentimento topofílico entre os agricultores difere enormemente de acordo com seu status socioeconômico" (TUAN, 1980, p. 112).

Nesse sentido de complexidade topofílica com o lugar, verifica-se uma dependência íntima dos indivíduos, uma vez que se sentem parte do lugar. Sobre essa consideração, Tuan explicita que "a topofilia do agricultor está formada desta intimidade física, da dependência material e do fato de que a terra é um repositório de lembranças e mantêm a esperança" (TUAN, 1980, p. 111), assim entende-se que familiaridade e afeição ajudam a determinar os valores topofílicos do lugar, logo, se os sentimentos são criados a partir das imagens e estas estão ligadas a realidade circundante do indivíduo, a memória tem papel fundamental nessa construção de percepção. Tuan afirma ainda que "a consciência do passado é um elemento importante no amor pelo lugar" (TUAN, 1980, p. 112).

\section{A agricultura urbana na cidade de São José dos Campos: o visível e o invisível}

O município de São José dos Campos, situado na região Sudeste do estado de São Paulo (Figura 1), ocupa uma área total de $1.099,6 \mathrm{~km}^{2}$, dos quais $353,9 \mathrm{~km}^{2}$ são considerados 
pertencentes à área urbana (32\%) e $745,7 \mathrm{~km}^{2}$ à área rural. É um dos principais municípios da Região Metropolitana do Vale do Paraíba e Litoral Norte. Dentre outras características de destaque, possui 52,36\% de seu território classificado como Área de Proteção Ambiental (PMSJC, 2012).

Há duas décadas, a cidade de São José dos Campos apresenta crescimento expressivo no setor de serviços, configurando-se como um centro regional do setor terciário que atende aproximadamente dois milhões de moradores da região do Vale do Paraíba e Sul de Minas Gerais (PMSJC, 2012). Com, aproximadamente, 700000 habitantes, de acordo com o IBGE (2017), cerca de $98 \%$ da população reside em áreas consideradas urbanas e apenas $2 \%$ dos domicílios situam-se nas áreas rurais (IBGE, 2012).

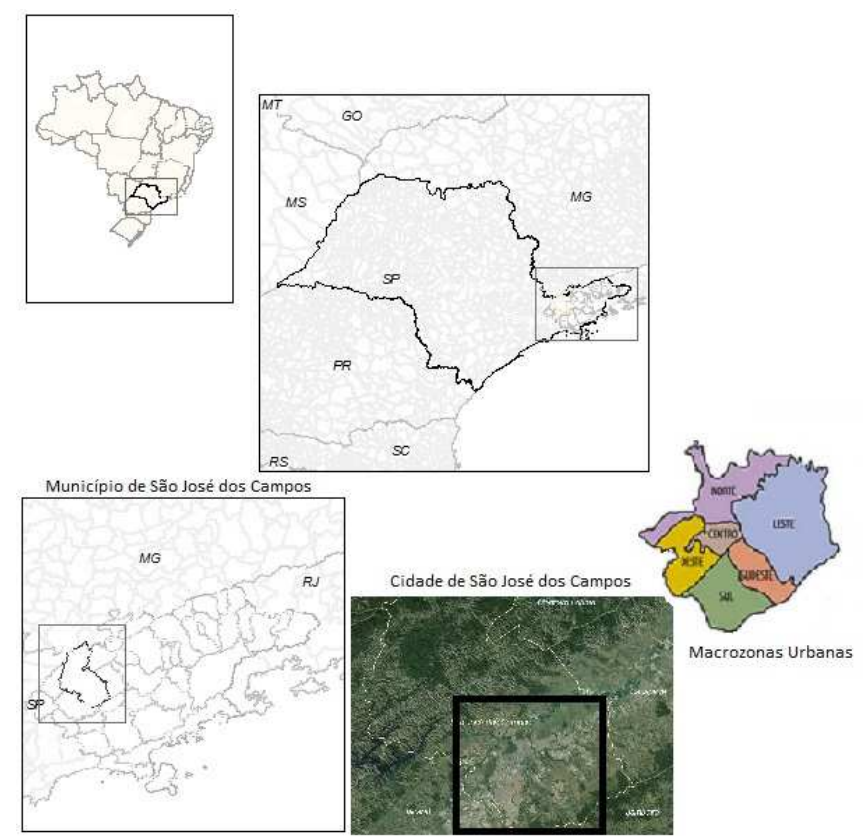

Figura 1 - Localização do município de São Joé dos Campos e de sua sede administrativa Fonte: Elaborada pelos Autores (2017)

Do ponto de vista demográfico, a Macro-Zona Norte, da cidade de São José dos Campos, ocupa a quarta posição num comparativo entre as macro-zonas mais populosas do município, apresentando cerca de 59.800 habitantes ( $9 \%$ do total) e uma média nunca superior a quatro habitantes e nem inferior a 2,8 habitantes por domicílio. De acordo com Oliveira, os moradores dessa Macrozona urbana possuem características muito distintas da realidade tecnológica e industrial da cidade. Em sua maioria, descendentes de imigrantes do 
estado de Minas Gerais, a população da região norte ainda preserva algumas características tradicionais das áreas rurais ou mesmo de pequenas cidades do interior do estado de Minas Gerais. Dentre essas características, o desenvolvimento da agricultura urbana chama atenção, principalmente no bairro Jardim Altos de Santana, onde moradores conservam características tradicionais do campesinato, desenvolvendo hortas urbanas na Área de Proteção Permanente dos rios Jaguari e Paraíba do Sul (OLIVEIRA, 1999).

A atividade agrícola do município não se restringe a área citada. Assim, a fim de diferenciar essas áreas e o tipo de agricultura existentes no perímetro urbano, tornou-se necessário se propor dois termos cabais ao entendimento da atividade em questão: a "agricultura urbana visível", que ocorre majoritariamente na área central do perímetro urbano; e a "agricultura urbana invisível", presente nos bairros, geralmente em várzeas de rios e córregos e fundos de vale, que suportam a atividade agrícola, via de regra, desenvolvida por moradores do entorno dessas áreas. Uma discussão um pouco mais aprofundada desses termos, é apresentada a seguir, para explicitar as diferenças entre as principais características da atividade agrícola presente em São José dos Campos.

\subsection{A agricultura urbana visível em são josé dos campos}

Primeiramente, há a necessidade de explicitar as razões pelas quais, nessa pesquisa, optouse por utilizar as nomenclaturas, associadas à atividade "agricultura urbana". Ao observar a realidade da cidade de São José dos Campos, em relação a essa atividade, o termo agricultura urbana foi dividido em dois nichos, nominados como "visível" e "invisível", importantes para o entendimento da proposta de análise da presente pesquisa.

Na cidade de São José dos Campos, a agricultura urbana e periurbana têm ocorrido de diferentes formas. Quando se trata daquela agricultura que ocorre aos olhos das pessoas, à ciência do Poder Público e é, explicitamente, parte da composição da paisagem urbana, optou-se pela denominação agricultura urbana visível. Nesse modal, a prática agrícola ocorre em espaços que, via de regra, se apresentam à dinâmica da paisagem de forma aparente, como uma área estritamente rural, porém, dentro do espaço urbano.

Uma área mais característica dessa agricultura urbana visível da cidade de São José dos Campos está situada na região central da cidade, em uma das áreas de várzea do rio Paraíba 
do Sul, conhecida como 'Banhado'. Essa área ocupa 6,28km2. Essa é uma Área de Proteção Ambiental (APA) estadual, que abrange a planície aluvial do Rio Paraíba do Sul. É caracterizada por terrenos baixos e planos, com declividade inferior a $5 \%$, onde os usos da terra mais frequentes são a agricultura e a pecuária, havendo indiretamente a conservação e preservação ambiental, que apresenta uma alta vulnerabilidade por diversos fatores e processos relacionados à urbanização (ANEEL, 1999).

Vale salientar que essas atividades se desenvolvem na área desde antes da derrubada da floresta, autorizada pela prefeitura, em 1912 (ROCHA, et al., 1996). O resultado dessa produção abastece o mercado interno joseense, fornecendo produtos ao Mercado Municipal e aos Centros Estaduais de Abastecimento e da Companhia de Entrepostos e Armazéns Gerais de São Paulo (CEASA/CEAGESP). Dessa forma, a agricultura urbana lá praticada, tradicionalmente, deve ser considerada visível.

No entanto, há a atividade da agricultura urbana que ocorre fora desse padrão de visibilidade, ou mesmo dessa centralidade geográfica da cidade de São José dos Campos. A esse modelo de agricultura optou-se pela denominação agricultura urbana invisível, tratada a seguir.

\subsection{A agricultura urbana invisível na cidade de São José dos Campos}

Em relação à agricultura urbana invisível, fica evidente a sua separação ao modal visível, descrito anteriormente, porém não se restringe apenas ao aspecto da paisagem a diferenciação básica entre esses dois modelos aqui apresentados. Quando se trata de agricultura urbana invisível, deve-se observar pelo menos duas características principais.

A primeira está voltada a ocorrência geográfica dessas atividades, uma vez que se localizam distantes da centralidade urbana, via de regra, nas zonas periféricas da cidade, quase sempre, áreas de habitação de população de baixa renda, ou mesmo que convivem com limitadores geográficos naturais (córregos, ribeirões, rios e suas áreas de várzea, além dos fundos de vale) ou antrópicos (rodovias, áreas industriais e de expansão da malha urbana), e terrenos baldios.

A segunda, trata especificamente do sujeito, do indivíduo produtor do cultivo e de relações, que, por não ter o reconhecimento visual de suas atividades, torna-se, ele também, além do território ocupado por ele, ser considerado invisível, assim como suas atividades e relações 
socais que estabelece. Combinadas, essas duas características culminam na segregação socioespacial do sujeito que se identifica com a atividade agrícola e tenta exercê-la dentro da malha urbana.

Pode-se contestar a validade dessas exposições frente à impressão de que pode ser considerada pequena a quantidade de indivíduos envolvidos na prática de tais atividades. Contudo, não querendo fazer juízo de valor quantitativo, mas utilizando esse viés para abordar o caso, não são poucas as áreas da cidade em que essas atividades ocorrem, espalhando-se por quase toda a malha urbana, nas áreas centrais ou periféricas. A figura 2 é uma representação generalista, pois várias outras áreas de agricultura urbana existentes no município não estão localizadas nesse croqui.

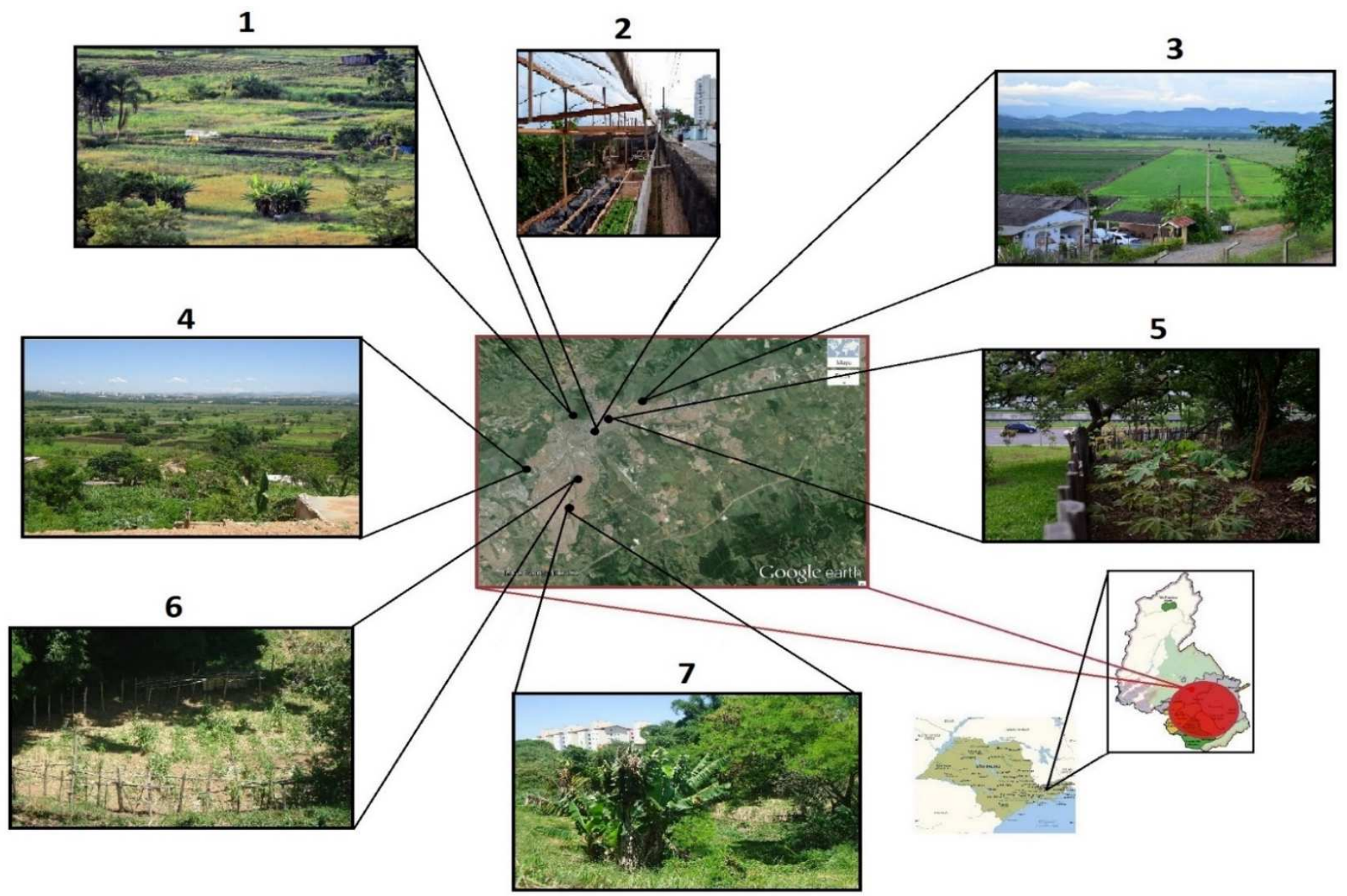

Figura 2: Agricultura urbana em São José dos Campos, SP. Fonte: Autores (2014).

Na zona oeste do município há pelo menos três bairros urbanos em que as atividades agrícolas ocorrem de forma ocultada. No Jardim das Indústrias e Jardim Limoeiro as áreas que margeiam o Banhado estão sendo ocupadas pela atividade em questão e recebem os cuidados dos moradores agricultores do local. No Jardim Pôr do Sol, (representado no 
mosaico pela imagem de número 4) a atividade ocorre principalmente em áreas cedidas pela empresa Monsanto ${ }^{\circledR}$ e próximas ao Córrego Ressaca (Figura 3).

Na porção leste, os bairros Vila Industrial, Vila Guarani e Vista Linda, (representados no mosaico pela imagem de número 3), têm seus limites com a área de várzea do rio Paraíba do Sul. Há a presença de hortas e pomares também cuidadas pelos moradores do entorno (Figura 4). Em área de vazio urbano, estabelecida pela passagem de cabos de energia, da EDP Bandeirante Energia, são encontradas hortas urbanas, cultivadas com autorização da empresa (Figura 5).

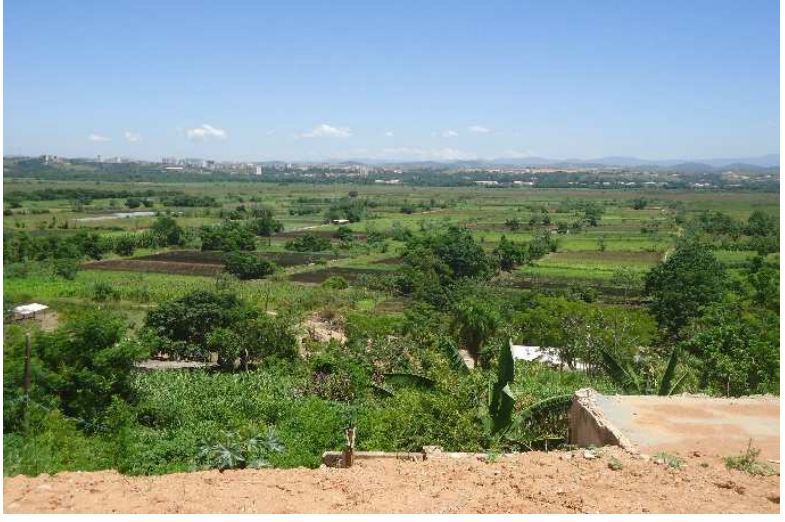

(a)

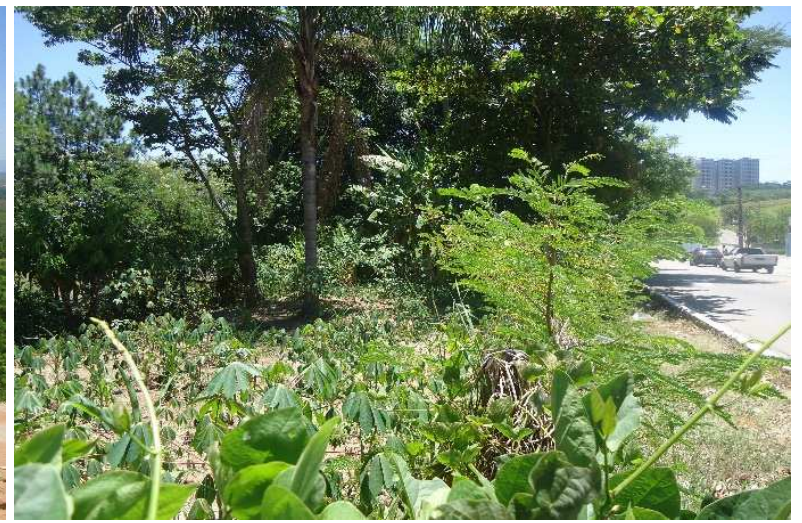

(b)

Figura 3: Agricultura urbana na zona oeste de São José dos Campos, SP: (a) área com agricultura urbana no Jardim das Indústrias; (b) plantio às margens da Rua Corifeu de Azevedo Marques, no Jardim Pôr do Sol.

Fonte: Autores (2014).

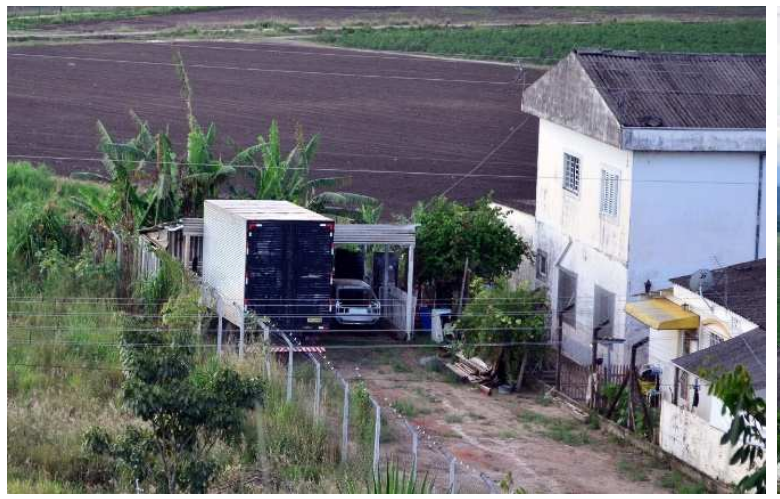

(a)

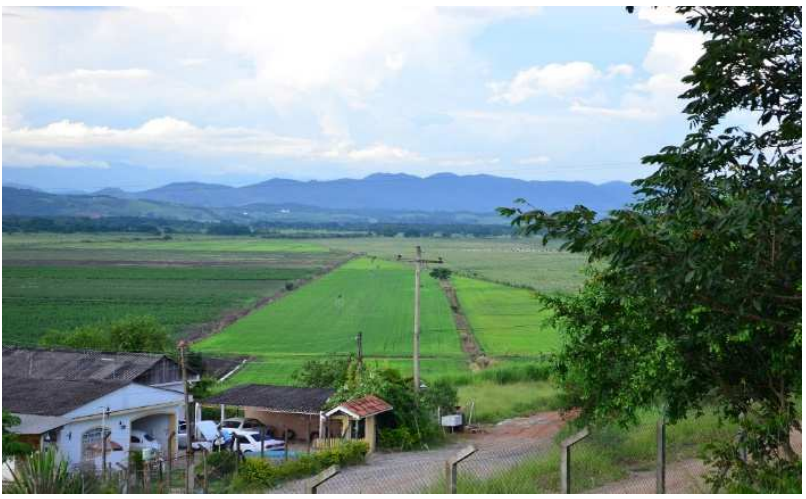

(b)

Figura 4: Agricultura urbana na zona leste de São José dos Campos, SP: (a) Área com policultura. (b) Área de monocultura.

Fonte: Autores (2014). 


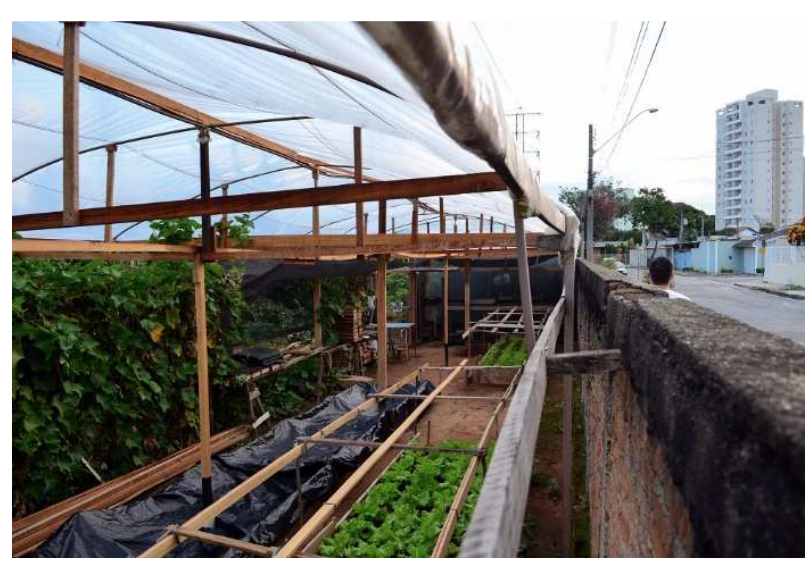

(a)

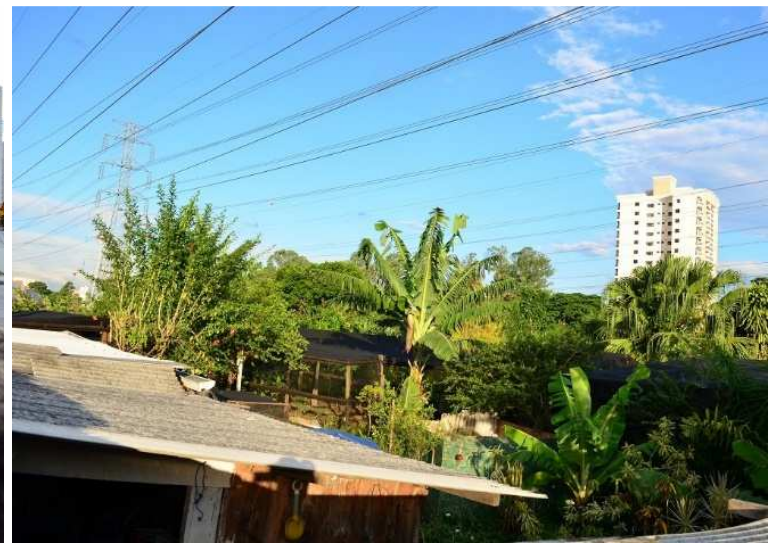

(b)

Figura 5: Agricultura urbana na área da EDP Bandeirante Energia, na zona central de São José dos Campos, SP: (a) Estufa com plantio de hortaliças. (b) Área de pomar.

Fonte: Autores (2014).

\subsection{Um exemplo de agricultura urbana invisível em São José dos Campos: o caso do Bairro}

\section{Jardim Altos de Santana}

O Bairro Jardim Altos de Santana, localizado no extremo norte da área urbana de São José dos Campos, possui algumas características específicas no que tange aos padrões de urbanização da cidade. Implantado há cerca de 30 anos, o bairro possui uma oferta de serviços privados e públicos. Há três unidades escolares, sendo duas escolas municipais de ensino fundamental e uma creche conveniada à prefeitura, além de um centro poliesportivo equipado com piscina, quadra de tênis, quadra poliesportiva, campo gramado para prática de futebol, pista de corrida, palco para eventos e salas para prática de atividades físicas indoor (Internas, cobertas), como a ginástica e artes marciais, com gratuidade de atividades físicas aos munícipes e moradores do bairro a adjacências. Somam-se a esses equipamentos públicos, uma unidade básica de saúde e uma pista para caminhadas que margeia o bairro em seus limites com os rios Paraíba do Sul e Jaguari. Próximo a essa pista de caminhada, há três quiosques localizados em pequenas praças equipadas com brinquedos para recreação infantil. Há ainda três equipamentos públicos de ginástica, denominados 'academias ao ar livre', uma próxima à pista de caminhada supracitada, outra em uma praça localizada na parte alta do bairro e mais uma integrada ao cento poliesportivo. Há ainda um PEV (Posto de Entrega Voluntária), que recebe resíduos da construção civil, eletroeletrônicos em desuso, podas de árvores, entre outros. Uma quadra poliesportiva fixada próxima à orla do 
rio Jaguari e duas quadras de areia, ambas em área de várzea dos rios.

É nessa área limítrofe, das várzeas dos rios, que ocorre a atividade de agricultura urbana no bairro. Quase todas as áreas que se encontravam livres ou abandonadas, localizadas nas áreas de várzea dos rios Jaguari e Paraíba do Sul, foram ocupadas com hortas e pomares desenvolvidas por moradores de diferentes locais do bairro, mas que têm, como atividade comum, a prática da agricultura urbana na área de proteção permanente dos rios supracitados (Figura 6). É importante ressaltar que esses moradores viabilizaram com recursos próprios a implantação das hortas e pequenos pomares, e que, quase sempre essa atividade de agricultura urbana representa muito mais um momento de lazer, contato com a terra e produção de alimentos para subsistência, do que uma atividade para fins comerciais, apesar de haver, no local, alguns moradores agricultores que comercializam sua produção agrícola excedente.

Os diferentes espaços são demarcados por cercas improvisadas pelos agricultores. Cada agricultor tem um espaço delimitado para sua prática e não há registro de conflitos entre eles quanto ao uso dos terrenos em questão. Os principais materiais utilizados para a delimitação das áreas são o arame preso a mourões e as cercas feitas de bambu. Todos os moradores agricultores se conhecem, o que facilita a comunicação entre eles.

Assim, analisando o recorte do mapa do Plano Diretor de São José dos Campos (PMSJC, 2006), a área em questão aparece demarcada como área reservada para implantação do nominado "Parque da Orla do Rio Paraíba do Sul" (Figura 7). Contudo, o que se observa é que essa demarcação se insere em sobreposição a área ocupada com a agricultura 'comunitária' (demarcada na cor vermelha na figura), o que evidencia, de acordo com levantamentos realizados com representantes da Prefeitura, a necessidade da retirada das hortas para implantação do Parque da Orla. Em 2012, a intenção do Poder Pública era eliminar as áreas de agricultura, onde seria implantado o Parque.

Em relação à postura da Prefeitura, em 2012, ao promover a retirada das hortas urbanas existentes no local, são ignoradas as práticas de agricultura urbana que reafirmam as características dos moradores agricultores do entorno, ocorrendo assim, a desvalorização de suas identidades, promovendo um cenário de perda de sua representação social.

Essa conjuntura vai contra as afirmações de Pollak, para quem a identidade é o "sentido da 
imagem de si, para si e para os outros, a imagem que uma pessoa adquire ao longo da vida referente a ela própria, a imagem que ela constrói e apresenta ao outro e a si própria, para acreditar na sua própria representação" (POLLAK, 1992, p. 205).

Acreditar em sua própria representação é o que imprime nesses moradores capacidade identitária. Isso fica evidenciado em seus relatos, havendo uma interdependência entre discurso e prática social, entre composição de identidade e representação socioespacial. Como os moradores enxergam a atividade desenvolvida? Quais os benefícios que retiram dessa prática? E a posição do Poder Público local, como se comportou ao longo desses anos, desde $2012 ?$

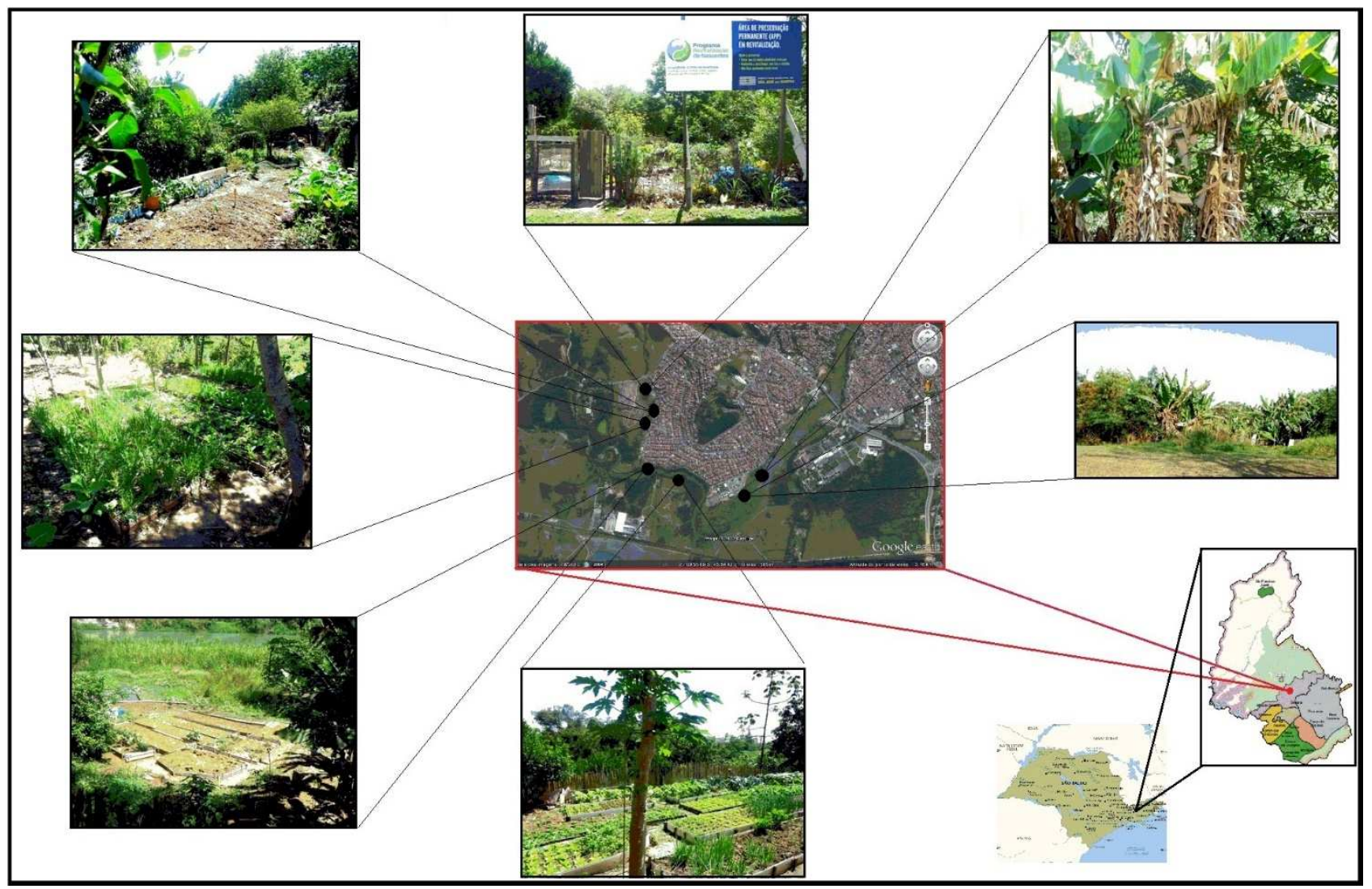

Figura 6: Agricultura urbana no bairro Jardim Altos de Santana, São José dos Campos, SP. Fonte: Autores (2013).

\subsubsection{Moradores agricultores e suas práticas agrícolas (in)visíveis}

A transcrição dos depoimentos, apresentados nesse item, tenta retratar e evidenciar que tipo de relação os moradores possuem com a área agricultada, buscando salientar o que se pôde investigar em termos de construção de sentimentos topofílicos e de pertencimento 
em relação à área de estudo, abordando o modo como os mesmos viabilizam suas hortas, organizam seus espaços e se relacionam entre si.

A visão do Poder Público, em 2012, sobre a área também é explicitada, afinal, via de regra, determina o viés de uso e ocupação das áreas públicas. No entanto, optou-se por iniciar a partir da análise dos depoimentos dos moradores por se acreditar que os indivíduos que se articulam cotidianamente com e pelo espaço possam ter contribuições mais profícuas sobre a dinâmica da área, bem como explicitar os (im)possíveis diálogos que ocorram entre eles e os representantes do governo.

De antemão, parece oportuno evidenciar que os moradores agricultores tenham desenvolvido relações topofílicas na área, o que fica claro ao se analisar discursos de um dos agricultores (Figura 8), que residem no bairro, desde a sua fundação, no início dos anos 1980.

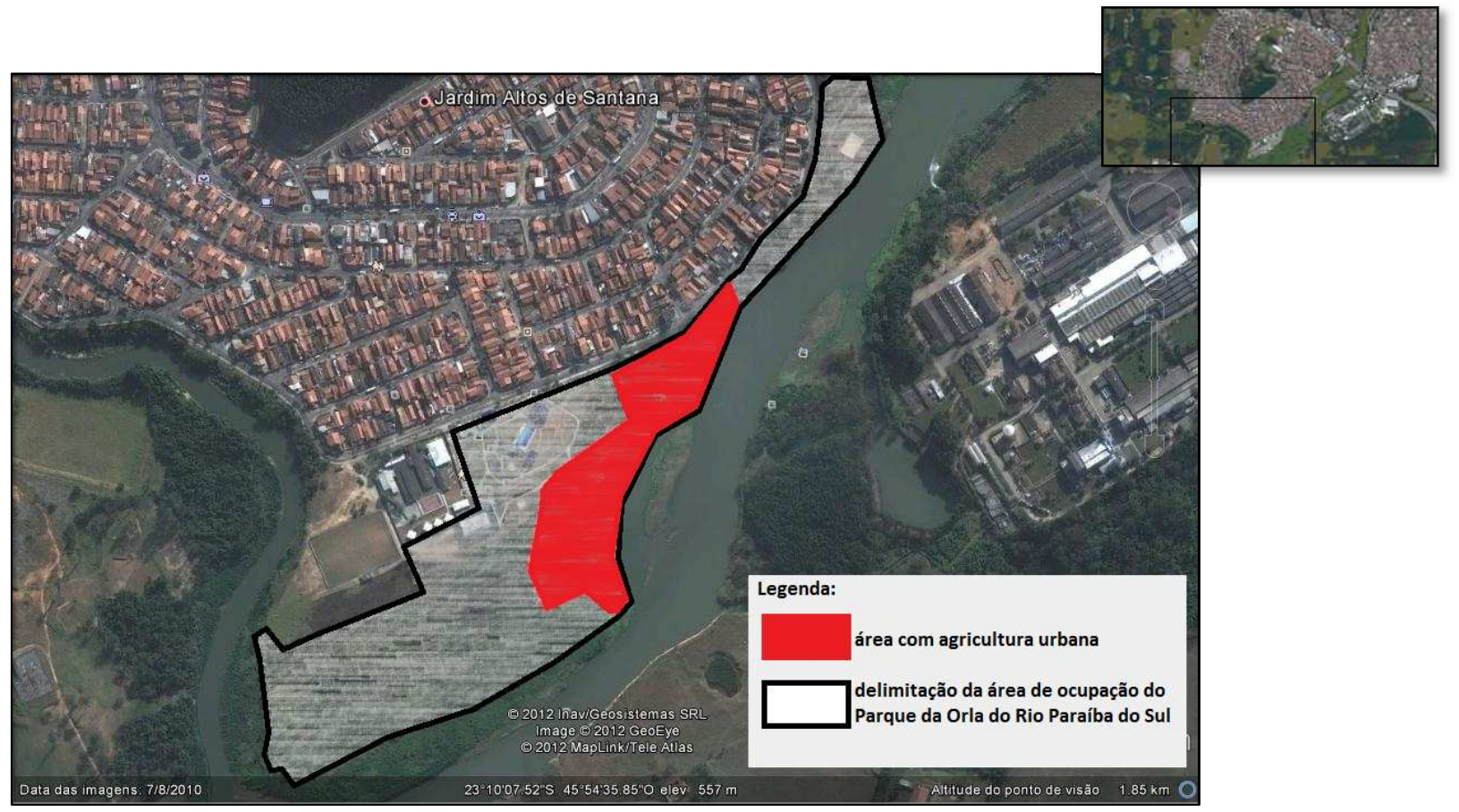

Figura 7: Jd. Altos de Santana - destaque para área com a prática da agricultura urbana e delimitação do Parque da Orla do Rio Paraíba do Sul.

Fonte: Elaborado pelo autor, a partir de imagens de satélite do Google Earth (2010). 
Quando questionado sobre seus sentimentos sobre a área, o agricultor A apresentou a seguinte opinião:

Eu sou chegado por causa disso aqui. [...] Ó lá o pé de amora que eu plantei (sic). Vamos entrar ali. Eu vou mostrar uma árvore pra você. O meu filho ganhou uma árvore lá na $\mathrm{Embraer}^{\circledR}$ e eu trouxe de lá, num dia que estava chovendo e pus aqui. Eu acredito que essa madeira quase não tenha aqui. Ele ganhou ela lá, mas desse tamanico (sic), assim ó (sic). Eu cheguei e pus aqui. Cheguei a trazer esterco de lá pra por aqui. No fim eu torci pra essa árvore sair, rapaz, porque eu ganhei mais árvores, mas essa ele trouxe da Embraer $^{\circledR}$ (depoimento fornecido em 09/11/2013).

Além de sua relação com a área denotar sentimentos topofílicos, esse agricultor ainda estabelece outras relações, ligadas aos seus laços familiares, ao dizer que ganhou muitas árvores para plantar, mas que tinha uma expectativa muito grande sobre uma muda, em especial, uma vez que quem a doou foi seu próprio filho, após ganhá-la na empresa Embraer $^{\circledR}$, seu local de trabalho.

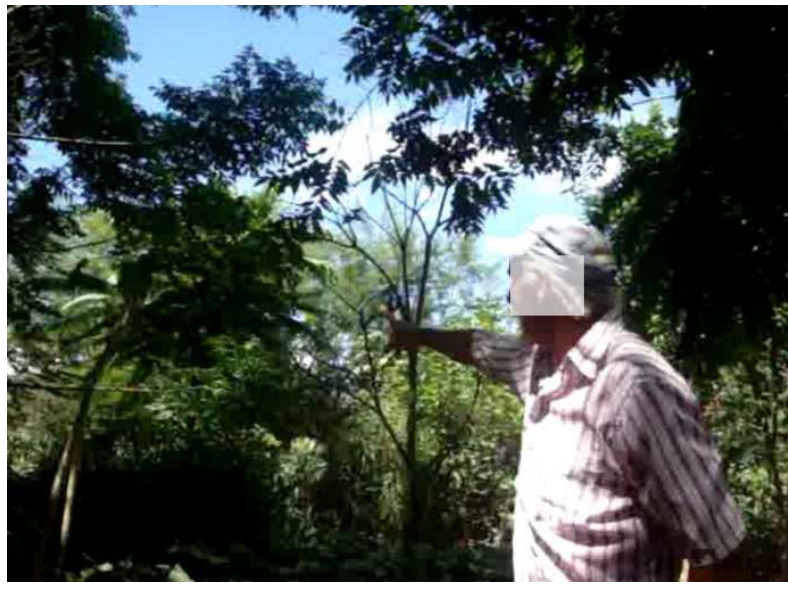

(a)

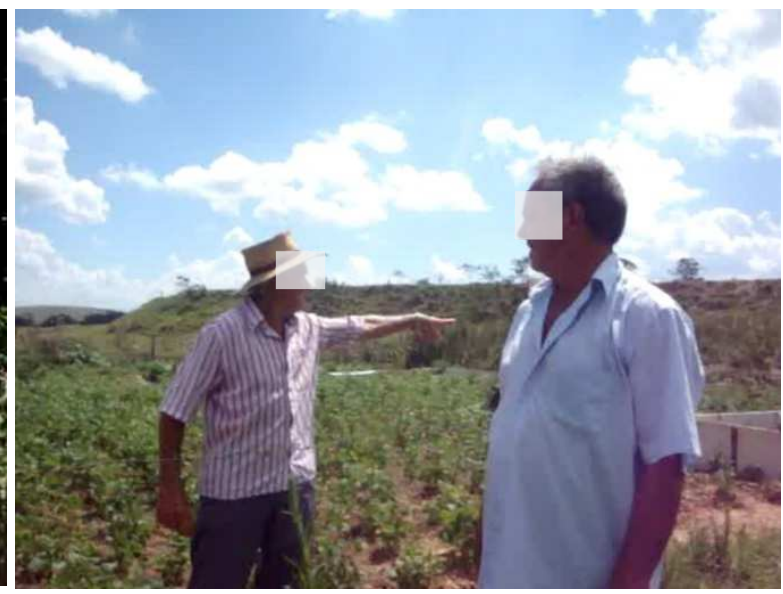

(b)

Figura 8: Agricultura urbana no bairro Jardim Altos de Santana, em São José dos Campos, SP. (a) $O$ Agricultor " $A$ " mostra árvore que foi ofertada por seu filho; (b) Agricultores que exibem área em preparo para receber o cultivo.

Fonte: Autores (2013).

Esse agricultor não é o único a apresentar esse tipo de sentimento para com o local onde desenvolve a agricultura. O Agricultor B, morador do bairro há cerca de dez anos, explicou que planta para o próprio consumo e que toda sua horta recebe adubação orgânica. Aposentado, hoje com mais de sessenta anos de idade, ele afirma que entende a atividade agrícola como um bom passatempo, pois o possibilita ter contato com a terra. Afirmou ainda que gosta muito do local onde desenvolve suas hortas, pois sempre morou em chácaras ou sítios e, agora no meio urbano, aproveita a experiência adquirida com a 
agricultura para ter uma ocupação, além de conviver com os outros moradores que compartilham sua prática.

Outro caso que se apresenta está ligado à história do Agricultor C, natural de Brasópolis, em Minas Gerais. Atraído pela possibilidade de melhores condições de sustento e empregabilidade, esse Agricultor passou a residir em São José dos Campos, desde os seus vinte anos de idade. Ele mora no bairro Jardim Altos de Santana, desde 1985. Atualmente, com setenta e cinco anos de idade, esse Senhor, enquanto apresentava sua área de cultivo, composta principalmente por mandioca e banana, explicou que a ocupa desde 1987, e que gosta muito do lugar e das atividades que desenvolve nela, pois neste espaço, que remonta seus ambientes de vivência ligados ao meio rural, se sente à vontade, pois pode, além de reviver seu passado, se dedicar a uma atividade que, em seu julgamento, é prazerosa. 0 Agricultor C menciona:

Eu gosto, eu fico a vontade, distrai, né? [...] planta, vai carpi (sic), levanta cedo. Tem dia que eu venho pra cá as seis horas. [...] Tendo, a gente vai plantando. Eu mexo aqui mais pra distrair né, porque na idade que eu to né? (Depoimento fornecido em 26/10/2013).

Um outro morador agricultor, envolvido com o cultivo, fala um pouco sobre as hortas e os cuidados que elas recebem dos moradores agricultores. Ele afirma que

Tem várias pessoas que plantam ali. Cada um cuida da hortinha deles. A turma respeita as árvores. [...] Quando eu vim, eu cheguei, logo já fizeram a cerca, mas a turma jogava lixo ali, porque a turma reclama que de primeiro (sic) era tudo sujo e bagunçado. Mas agora não, porque nós, além de plantar nós cata lixo, sacolinha essas coisas, mas além de plantar a gente ajuda a limpar (depoimento fornecido em 08/11/2013).

Mesmo que de forma sucinta, entende-se que esses depoimentos evidenciam os sentimentos dos moradores para com a área. Nota-se, em seus relatos, que a relação dos agricultores com a terra tem raízes muito além do território em si, uma vez que a maioria deles já agricultava em outras localidades, antes mesmo de chegarem ao bairro, ou mesmo a São José dos Campos. São sentimento que nos remetem às discussões de Tuan, que afirma que "o lugar ou o meio ambiente é o veículo de acontecimentos emocionalmente fortes" (TUAN, 1980, p. 107), evidenciando a existência de sentimentos topofílicos pela área.

Uma contabilização preliminar demonstrou que há, pelo menos, 40 agricultores diferentes plantando em todo o bairro. Alguns, que plantam na área há mais tempo, afirmam possuir um documento expedido pela Prefeitura Municipal que os autoriza a utilizar as áreas para o plantio, desde que não sejam utilizadas para fins de construção de moradias. Um dos 
Agricultores entrevistados explica um pouco sobre essa documentação:

Quando eles liberaram pra nós plantar (sic), foi a Prefeitura que liberou aqui, eu tenho papel, eu tenho tudo que tá em casa. [...] Aí falaram, não, pode plantar, só pra plantar e quando a gente precisar a gente tira, aí eu falei, tá bom, ué não é nossa a área, o terreno não é da gente (depoimento fornecido em 26/10/2012).

O Agricultor D, atualmente, com quarenta anos de idade, relata que, ainda aos quinze, seu pai também obteve esse documento da Prefeitura, que o permitia a utilização da área para fins de plantio. Disse ainda que todos os moradores que utilizavam a área na época receberam o tal documento, que está em seu poder, para o caso de precisar comprovar o uso legal da área. Sendo assim, esse documento que foi expedido há mais de vinte anos, evidencia que o Poder Público Municipal oficializou, de alguma forma, as atividades agrícolas que ocorrem no bairro, ou pelo menos que este tem conhecimento de tais práticas. Assim, esperava-se que a administração municipal devesse incentivar a atividade de cunho agrícola no bairro, pois reconhecendo sua existência e autorizando a prática, denota uma valorização das identidades criadas e reforçadas na área em questão. Porém, atualmente, a Prefeitura e seus representantes têm demonstrado interesses diferentes para a área em questão. Essa afirmação fica evidente se analisado o Plano Diretor do município, que data do ano de 2006, como apresentado anteriormente. De acordo com o documento (PMSJC, 2006), na seção de mapas de parques urbanos, na mesma área onde ocorre a agricultura urbana, está prevista uma intervenção para criação do Parque da Orla do Rio Paraíba do Sul, que para ser instalado deverá promover a retirada das hortas e pomares cuidados pelos moradores agricultores presentes no bairro.

\section{O poder público e a criação de parques lineares em São José dos}

\section{Campos}

Ficou evidente que a antes mesmo de haver a criação da agricultura urbana no bairro Jardim Altos de Santana, os próprios moradores a tinham criado neles. A necessidade e o prazer no trabalho junto à terra e a prática agrícola já estavam, antes mesmo de sua chegada ao bairro, introjetadas em seu fazer cotidiano, seus hábitos, seus comportamentos. O prazer relatado pelos produtores urbanos do bairro demonstra que há uma sedimentação dos 
sentimentos topofílicos criados e, às vezes, até antes de seu acesso ao bairro, demonstrando que a memória se apresenta como fator preponderante na afirmação da identidade e na criação e manutenção dos laços afetivos do indivíduo com o lugar.

Uma vez estabelecida, quase que organicamente, a agricultura urbana no bairro Jardim Altos de Santana, na várzea dos rios Paraíba do Sul e Jaguari, utiliza métodos considerados sustentáveis para sua manutenção, e utiliza insumos agrícolas ou quaisquer tipos de adubação que não seja feita por meio do processo de compostagem (técnicas aplicadas para estimular a decomposição de materiais orgânicos.) A água utilizada para irrigação das pequenas hortas e pomares também é retirada das áreas de nascente que afloram na várzea, ou mesmo do curso rio Paraíba do Sul, através de bombeamentos. Os espaços destinados às hortas e pomares são delimitados por cercas de arame e bambu e cada morador agricultor tem destinado a si um espaço para plantio, respeitado pelos outros moradores e pelos moradores do entorno, mesmo os que não trabalham a terra, já que há evidente apreço pela atividade desenvolvida e valorização social dos próprios moradores agricultores, que se ajudam entre si 'vigiando' os espaços agricultados.

Há explicitamente a criação, mesmo que não intencional, de uma rede de produção de alimentos, aceita pelos moradores do bairro e que conflitam com a criação do Parque da Orla do Rio Paraíba do Sul. Assim, resta indagar se o relato dos agricultores e o acompanhamento de suas práticas não tornam legítima a necessidade de acompanhamento e diálogo com o Poder Público, que até o momento mostrou-se indiferente a essas atividades de cunho socioambientais.

Os possíveis impactos da implantação do Parque da Orla do Rio Paraíba do Sul parecem não fazer parte do entendimento dos governantes, nas duas gestões públicas, com ideologias partidárias diferentes, que foram pesquisadas (2009-2012 e 2013-2016). Tanto no viés ambiental, que trata especificamente dos impactos que a implantação de um parque urbano pode trazer a uma área de várzea, quanto do ponto de vista social, ignorando as práticas de agricultura urbana presentes na área pesquisada, bem como os modos de vida e, porque não dizer, a própria população que reside na área. Assim, evidencia-se que o Poder Público apresenta uma visão turva frente ao caso. Indaga-se aqui, se essa turbidez de análise política, explicitada por meio das pesquisas realizadas, deve-se ao fato do quase completo e inconsciente ignoro das causas ligadas às populações ditas invisíveis, ou se de 
fato, os moradores são ignorados conscientemente, em uma prática que pode representar uma estratégia dos representantes do governo municipal em postergar as discussões pertinentes ao caso, ou mesmo se representam ainda um esforço de tentar suprimir e tornar invisíveis tais modos de vida, que por alguma crença, pareçam desinteressantes a uma cidade que parece aspirar por uma modernidade idearia que contradiz a realidade cotidiana.

Comparando as visões das gestões públicas pesquisadas, ficou evidente que num primeiro momento, o impacto ambiental de um processo urbanizador é deixado de lado, e que, num segundo momento, os impactos sociais é que são minimizados. Na gestão 2009-2012, os representantes da Secretaria de Meio Ambiente alegaram que o Parque da Orla do Rio Paraíba do Sul não traria impacto em sua implantação, pois retiraria apenas as espécies vegetais exóticas, o que, no entendimento da mesma, seria o necessário para isentar suas responsabilidades de impactos ambientais do processo urbanizador. Ressalta-se que os moradores agricultores, presentes na área de várzea manejam as hortas por meio da cultura de sementes crioulas (não modificadas geneticamente) e utilizam insumos orgânicos, além de aproveitar a água presente no próprio local de suas plantações, seja ela proveniente de nascentes ou do próprio rio Paraíba do Sul, o que configura as práticas agrícolas como sustentáveis, restando assim questionar se essas práticas relatadas causam, realmente, mais impacto a uma área de várzea do que o processo de urbanização previsto no Plano Diretor.

Na gestão 2013-2016, sequer houve a oportunidade de consultar os representantes da Secretaria do Meio Ambiente de São José dos Campos, pois os mesmos, por meio de assessores, recomendaram que todo assunto referente a implantação de parques urbanos, mesmo que em áreas de várzea, deveria ser tratado diretamente com a Secretaria do Planejamento Urbano do município, entendida como responsável pelo caso. Parece notório que a implantação de todo e qualquer parque urbano em APP (Área de Proteção Permanente) atinge a seara socioambiental, cabendo, portanto à Secretaria do Meio Ambiente da cidade de São José dos Campos apresentar argumentos que comprovem a viabilidade do parque ou somente a Secretaria de Planejamento Urbano é que merece esclarecer tais questões de foro tão particular às premissas socioambientais?

Sobre a necessidade de diálogo com a população, o discurso de ambas as administrações é uníssono: consideram importante que haja aproximação entre o Poder Público e os 
munícipes, no entanto, em ambos os casos, assumem que não o fizeram até o momento, alegando as mais diversas justificas. Cabe aqui o questionamento sobre o modelo de aproximação desejado pelos governantes de ambos os períodos referentes a pesquisa: seria essa aproximação dialética, ou somente mais uma ação unilateral, atuante em discurso monólogo, onde os munícipes têm definido o papel da escuta, imprimindo-lhes certa liberdade dirigida de acompanhar um possível contato ainda inexistente?

\section{Considerações finais}

As práticas de agricultura urbana presentes em São José dos Campos são diversificadas. Em toda malha urbana, recortes e mais recortes territoriais são preenchidos por essas atividades, que ocorrem, preferencialmente em terrenos, espaços privados, fundos das moradias, quintais, terreiros, áreas de concessão, áreas públicas e de proteção ambiental, entre outras. O desejo de mapear, pesquisar, entender todas elas e os modos de vida nelas presentes, foi latente, porém não coube ao fôlego dessa pesquisa realizar tal demanda, aqui entendida com uma fraqueza explícita da produção acadêmica apresentada.

No tocante a pesquisa realizada e seus produtos qualitativos, desde a fundação do bairro Jardim Altos de Santana, no início da década de 1980, ocorrem práticas de agricultura realizadas por moradores que apesar de habitar um bairro considerado urbano, conservam características campesinas. Eles alegam o direito de utilização das áreas agricultadas, pois a maioria deles possui documentação expedida pela Prefeitura para o desenvolvimento da atividade ou ainda porque utilizam a área há mais de vinte anos.

O Poder Público, em ambos os períodos de gestão pesquisados, pretende outro uso para a área agricultada, instalando um parque com equipamentos urbanos. Contudo, em nenhum momento os moradores do bairro foram consultados sobre essa ação, o que demonstra que essa situação parece ser invisível aos olhos do Poder Público, restando considerar quais seriam as dimensões referentes ao impacto causado aos moradores agricultores e suas práticas caso ocorra a implementação do Parque da Orla do Rio Paraíba do Sul.

É a produção dos significados simbólicos que confere identidade a um povo, uma 
população, um grupo. O respeito a essa possibilidade, de manutenção de modos de vida, motivação principal dessa pesquisa, parecem merecer maior visibilidade e respeito, até porque, caso ocorra esse encaminhamento, vê-se a possibilidade de mudança de postura da população diante das questões ambientais e do Poder Público diante da população e de seus anseios. Acredita-se que essas questões e práticas, mais particulares devam ser tratadas a partir de seu viés mais etimológico, em que se busque o entendimento do 'partícula', item fundamental e 'menor' de cada objeto, mas que compreendido em suas minúcias, ajuda a dar sentido ao todo observado.

\section{Agradecimentos}

Os autores agradecem à Coordenação de Aperfeiçoamento de Pessoal de Nível Superior (CAPES), pelo apoio fornecido ao desenvolvimento dessa pesquisa.

\section{Referências bibliográficas}

ABIKO, A. K. Urbanismo: história e desenvolvimento. São Paulo: USP - Poli, 1995. Disponível em:<http://www.pcc.usp.br/Gradução/pcc567/textotecnicPCC16.pdf>.

AGÊNCIA NACIONAL DE ENERGIA ELÉTRICA - ANEEL. Projeto qualidade das águas e controle da poluição hídrica: Programa de Investimentos para a Gestão Integrada e Recuperação Ambiental da Bacia Hidrográfica do Rio Paraíba do Sul. Brasília: ANNEL, 1999.

ALMEIDA. D. A. O. Agricultura urbana e agroecológica na região metropolitana de Belo Horizonte. Belo Horizonte: Editora da UFMG, 2011

ARRUDA, J. J. A. História antiga e medieval. 16a Ed. São Paulo, Editora Ática, 1993. ISBN 978-85-080-1262-6.

BRASIL. Casa Civil. Subchefia de Assuntos Jurídicos. Lei 012.651 de 25 de maio de 2012. Dispõe sobre a proteção da vegetação nativa; altera as Leis nos 6.938, de 31 de agosto de 1981, 9.393, de 19 de dezembro de 1996, e 11.428, de 22 de dezembro de 2006; revoga as Leis nos 4.771, de 15 de setembro de 1965 e 7.754, de 14 de abril de 1989, e a Medida Provisória no 2.166-67, de 24 de agosto de 2001; e dá outras providências. Disponível em: http://www.planalto.gov.br/ccivil_03/_ato2011-2014/2012/lei/112651.htm. Acesso em: 17 de maio 2016.

CARLOS, A. F. A. A questão da cidade e do campo: teorias e política. Mercator- Revista de Geografia da UFC, ano 03, n. 05, 2004. Disponivel em: <http://www.mercator.ufc.br/index.php/mercator/>>. Acesso em 20 jul. 2016.

COUTINHO, M. Agricultura Urbana, reflexão e análise sobre os marcos legais e normativos do município de Belo Horizonte. Monografia de Graduação. Belo Horizonte: IGC, UFMG, 2007. 
DONADIEU, P. Campagnes Urbaines. Arles: Actes Sud, 1998, ed. it. MININNI, M. (Org.). Campagne urbane: una nuova proposta di paesaggio della città. Roma: Donzelli, 2006. ISBN 978-88-603-6966-6.

GOTTDIENER, M. A produção social do espaço urbano. São Paulo: Editora da Universidade de São Paulo, 1993. ISBN 978-85-314-0102-2.

IBGE. Censo Demográfico 2000-2010. Disponível em: http://www.censo2010.ibge.gov.br/primeiros_dados_divulgados/index.php. Acessado em 04 fev. 2012.

IBGE. Censo Demográfico 1960, 1970, 1980, 1991, 2000 e 2010. Disponível em: http://www.censo2010.ibge.gov.br/sinopse/index.php?dados=9\&uf=00. Acesso em 04 fev. 2012.

INGERSOLL, R.; FUCCI, B.; SASSATELLI, M. (Org.). Agricoltura urbana: dagli orti spontanei all'agricivismo per la riqualificazione del paesaggio periurbano. Bologna: Regione Emilia-Romagna, 2007.

MADALENO, I. M. A cidade das mangueiras: agricultura urbana em Belém do Pará. Lisboa: Fundação Calouste Gulbenkian, 2002. ISBN 978-97-231-0951-1.

MANFIO, V. O papel da CAMNPAL na (re) estruturação do espaço urbano de Nova Palmas - RS. 2011. Dissertação (Mestrado em Geografia e Geociências) - Universidade Federal de Santa Maria, Centro de Ciências Naturais e Exatas, Santa Maria, RS, 2011.

MARQUES, M. I. M. O Conceito de espaço rural em questão. Terra Livre, Rio de Janeiro, n. 19, p.95-112, 2002.

MOUGEOT, L. J. A. Urban agriculture: definition, presence, potential and risks. In: BAKKER, N.; DUBBERLING, M.; GUNDEL, S.; SABEL-KASCHELLA, U.; ZEEUW, H. (Ed.). Growing cities, growing food: urban agriculture on the policy agenda. Feldafing: DSE, 2000. p. 1-42. ISBN 978-39-340-6825-4.

OLIVEIRA, J. O. S. Santana: São José dos Campos: evolução histórica e diretrizes urbanas. São José dos Campos, SP: Takano, 1999. ISBN 978-85-900-8131-9.

POLLAK, M. Memória, esquecimento, silêncio. Estudos Históricos 3. Rio de Janeiro, vol. 5, n. 10, 1992, p. 200212.

PREFEITURA MUNICIPAL DE SÃO JOSÉ DOS CAMPOS - PMSJC. Caracterização da cidade. Disponível em: <http://www.sjc.sp.gov.br/cidade/caracterizacao.aspx>. Acesso em: 11 set. 2012.

PREFEITURA MUNICIPAL DE SÃO JOSÉ DOS CAMPOS - PMSJC. Lei Complementar 306/2006 - Plano diretor da cidade de São José dos Campos: parques urbanos. Disponível em: <http://www.sjc.sp.gov.br/media/24473/07lc306parquesurbanos.pdf>. Acesso em: 22 set. 2013.

SANTANDREU, A.; LOVO, I. Panorama da agricultura urbana e periurbana no Brasil e diretrizes políticas para sua promoção: identificação e caracterização de iniciativas de agricultura urbana e periurbana em regiões metropolitanas brasileiras. Mimeo, 2007. Disponível em: <http://www.rede_mg.org.br/?iid=56>. Acesso em: 05 fev. 2012.

SANTOS, M. Espaço e Método. São Paulo: Nobel, 1997. ISBN 85-213-0294-0.

SANTOS, M. Técnica, Espaço, Tempo, Globalização e Meio Técnico-Científico-Informacional. São Paulo: Hucitec, 1994. ISBN 978-85-314-1049-9

SANTOS, M. Metamorfoses do Espaço Habitado: Fundamentos Teóricos e Metodológicos da Geografia. 6a Ed. São Paulo, Edusp, 2008. ISBN 978-85-314-1044-4.

SMIT, J.; RATTA, A.; NASR, J. (Org.). Urban Agriculture: food, jobs and sustainable cities. Vol. one, Publication series for Habitat II. New York: UNDP, 1996

TUAN, Yi-fu. Topofilia. Um estudo da percepção, atitudes e valores do meio ambiente. São Paulo: Difel, 1980. ISBN 978-85-721-6627-0.

VAINER, Carlos Bernardo. Utopias urbanas e o desafio democrático. Revista Paranaense de Desenvolvimento, Curitiba, n. 105, p. 25-31, jul./dez. 2003. 